\title{
Research on Tourist's Propagation Effect of Online Word of Mouth Communication Under Tourism Destination Context*
}

\author{
Xiaoyan Liu \\ School of Business Administration \\ Jianghan University \\ Wuhan, China
}

\begin{abstract}
The potency, intensity and quality of information on the online word-of-mouth communication of tourism destinations will positively affect the willingness of word-ofmouth recipients to re-transmit. However, in terms of purchase intention, the potency of information will adversely affect the willingness of the word-of-mouth recipient to purchase. The credibility of the information channel is positively affecting the re-distribution willingness and willingness of the word-ofmouth recipients. This also means that the more professional, formal, and large company-based communities or software will be favored by more word-of-mouth recipients, thus making the willingness to re-transmit will increase. In terms of purchase intention, the ability to pay can stimulate their willingness to purchase, and product involvement will also stimulate purchase intention, but in terms of re-distribution willingness, the altruistic motivation does not stimulate their willingness to re-transmit as imagined.
\end{abstract}

Keywords-tourist destination; online word of mouth; propagation effect

\section{INTRODUCTION}

With the development of the Internet, online word-ofmouth marketing has gradually become the focus of research and practice. Online word-of-mouth refers to the exchange and discussion of information about a certain product or service by Internet users through a series of online mediabased communication tools such as BBS, Web Product Discussion Area and Blog. Regarding the online word-ofmouth communication effect as the influence, reaction and effect of online word-of-mouth communicators, the effect of online word-of-mouth communication can be divided into positive effect and negative effect according to the effect. Positive word-of-mouth in the process of online word-ofmouth communication often brings positive and positive effects, and negative word-of-mouth produces negative and negative effects. In this study, the author focuses on measuring the subject of the word-of-mouth in tourism destination information network. The online word-of-mouth consumer effect mainly corresponds to the purchase

*Fund: the paper was funded by the Doctoral Research Project of Jianghan University "Research on Online Word of Mouth Communication under Tourism Destination context." intention and other influences of tourists, such as repropagation.

\section{THEORETICAL B ACKGROUND AND HYPOTHESES}

Online word-of-mouth communication initiator and recipient are all nodes in the network. The re-distribution willingness of word-of-mouth recipients determines the speed and propagation of word-of-mouth in the network, and the word-of-mouth recipients who are more willing to propagation will quickly propagation to as many other recipients as possible; Weak word-of-mouth recipients will stop propagationing or only propagation to a small number of other recipients. From the perspective of complex networks, it can be easily found that one of the important measures of online word-of-mouth communication effect is the willingness of recipients of word-of-mouth information to re-transmit

The second effect of online word-of-mouth communication should be reflected in purchase decision. Online word-of-mouth is an important decision-making basis for consumers to reduce search costs and perceived risks in the current environment of asymmetric information Kozinets (1999) examined the importance of online word-ofmouth to consumers and verified the above. Zhou (2011) found that the intensity, quality and quantity of online wordof-mouth information significantly affect consumers' online travel booking decisions, and the perceived risk of consumers is in the relationship between negative online word-of-mouth and consumer purchasing decisions. Lao (2014) used empirical analysis to study the relationship between online word-of-mouth quality and consumers willingness to purchase. Finally, it was concluded that the quality of online word-of-mouth has a significant positive impact on perceived quality, purchase intention and customer trust.

Through the above analysis, it can be found that there are two kinds of effects of the online word-of-mouth communication effect, one is the willingness to re-transmit, and the other is the willingness to purchase. The willingness to re-transmit in the online word-of-mouth communication effect is affected by many factors. In general, it is divided 
into four directions: information level, which mainly includes the potency, intensity and quality of information; channel level, which mainly includes website credibility; source credibility, including sender professionalism, objectivity, relationship strength and reliability and recipient level, including product involvement and altruistic motivation.

The willingness to purchase in the word-of-mouth communication effect is also affected by many factors. Lao (2014), Zhang (2013), Cheng (2011), Chai (2011), Chen (2008) verified the variables proposed are basically above, but from the view of marketing, the influence of the purchase intention is not only factors listed above, but also the ability to pay, which influence actual decision-making behavior and purchase intention. If there is no ability to pay, the will is unlikely to occur. Therefore, in the influencing factors of purchase intention, the recipient should add a variable and ability to pay; Zhou (2011) and Tie (2011) also agreed with this view, and both believed that the altruistic motivation was an important influence of the recipient's willingness to retransmit. Factors should not be included in the purchase intention model, so in this effect, less altruistic motivation for this variable.

\section{A. Information Level}

In the previous research on word-of-mouth, most of the empirical research has measured the word-of-mouth content, such as measuring word-of-mouth frequency and word-ofmouth. Only a few studies focus on the characteristics of consumer word-of-mouth information itself (Luo, 2007). For example, the content, style and tone of the information studied by Chan (2000); Zhang (2008) summarizes that researchers are more inclined to Chevaller (2006) when measuring Internet word of mouth. The assertion is that the titer is only the level of evaluation (high to positive, low to negative). Secondly, regarding the strength of online wordof-mouth information, it is understood from another level, that is, the number of online word-of-mouth information. Liu (2006) studied the movie box office and movie reviews and found that the number of online comments on a movie can be said to be a barometer of the movie. This is an example of the significant impact of online word-of-mouth intensity on purchase intention. (1987) has proved, and Chai (2011) via empirical research to verify that the number of online wordof-mouth can positively influence consumers' willingness to re-transmit in tourism. Finally, Chen and Zhang (2008) believe that the most important one of the content characteristics of online word-of-mouth communication is fun.Cheng (2010) believes that the intensity of word-ofmouth information is mainly reflected in fun and vividness. In summary, the following is assumed:

H1a: The information titer on the word-of-mouth information of a particular tourist destination will positively affect the willingness to re-distribute online word-of-mouth;

H1b: The information intensity of word-of-mouth information about a particular tourist destination will positively affect the willingness to re-distribute online wordof-mouth;
H1c: The quality of information about the word-of-mouth information of a particular tourist destination will positively affect the willingness to re-distribute online word-of-mouth;

H2a: Information valence about word-of-mouth information for a particular destination will positively affect the willingness of the recipient of the purchase;

$\mathrm{H} 2 \mathrm{~b}$ : The intensity of the information about the word-ofmouth information of a particular destination will positively affect the willingness of the recipient to purchase the information;

H2c: The quality of information about word-of-mouth information for a particular destination will positively affect the willingness of the recipient of the purchase.

\section{B. Channel Source Credibility Level}

Zhang (2004) believes that the measurement of information credibility is mostly used in the sender and use of word of mouth. Hovland et al. (1953) believed that the influence of information is affected to some extent by the channel through which it passes. Fu (2008) believes that the network platform that is recognized by everyone has a high degree of credibility, which will affect consumers' confidence and promote consumers to absorb the word-ofmouth information disclosed on the network platform. In addition, some scholars believe that the use and dependence of the media by more people can increase its credibility. This is an important criterion for the network society, that is, the more users, the snowball effect will be formed. On the other hand, people also have great bias towards their favorite media, and audiences often believe in their own judgment (Rimme \& Weaver, 1987). Zhang Mingxin (2004) emphasizes this point of view. He believes that audiences can make decisions about their actions through these trusted media. Parkand Lee (2007) used reputation to replace the measure of website credibility. They found that the reputation of a better-known website was much more effective. Xu Lin (2007) found that the credibility of channels directly affects consumers' purchasing decisions, because in the network age, the credibility of online platforms often becomes an important judgment of consumers on the credibility of information. Cheng Lei (2010) adopted Hovland's (1953) concept judgment on credibility. He combined media credibility with sender credibility to verify its positive impact on the re-distribution willingness of information recipients. Combined with the research conclusions of scholars such as Xu Lin (2007) and Cheng Lei (2010), the following can be assumed:

H3: The credibility of the target information channel (website) is positively affecting the willingness of the recipient of the information to re-transmit;

H4: The credibility of the target information channel (website) is positively affecting the willingness of the information recipient to purchase.

\section{Communicators Source Credibility Level}

As mentioned earlier, Hovland (1953) has defined the credibility of the source, which is divided into three levels: 
communicator, information itself and media. These three levels jointly build the credibility of the source, but the author uses it in this study. Zhang (2004) points out the separation of the credibility of the communicator and the media. This part of the hypothesis is mainly used to verify the source credibility of the communicator. Some studies believe that the characteristics of online word-of-mouth communicators directly affect the effect of word-of-mouth communication. Gilly (1998) and Bansal (2000) found that the higher the professionalism of information sources issued by traditional word-of-mouth communicators, the more the word-of-mouth recipients will be affected by purchasing decisions; Smith (2003) verified that this conclusion is true in the network environment. Bickart (2001) conducted a pilot study on the online information and the spontaneous information of netizens, and found that consumers are more interested in netizens' information and believe that it is reliable and more directly affected. Goldenberg (2007) found that relationship strength positively affects the effect of online word-of-mouth communication. Luo et al (2008) found that in traditional word-of-mouth communication, the stronger the relationship, the greater the influence of wordof-mouth; in terms of online word-of-mouth, the relationship strength There is no significant effect on word-of-mouth effect. Therefore, this study incorporates the strength of the relationship between the communicator and the recipient into the scope of the study, and explores the impact of the intensity of the relationship on the effect of online word-ofmouth communication.

Based on the above analysis, this paper proposes the hypothesis:

H5a: The professionalism of the sender of the tourist destination information positively affects the recipient's willingness to re-transmit;

H5b: The reliability of the sender of the tourist destination information positively affects the recipient's willingness to re-transmit;

H5c: The objectivity of the sender of the tourist destination information positively affects the recipient's willingness to re-transmit;

H5d: The strength of the relationship between the sender and the recipient of the tourist destination information positively affects the recipient's willingness to re-transmit;

H6a: The professionalism of the sender of the tourist destination information positively affects the recipient's willingness to purchase;

H6b: The reliability of the sender of the tourist destination information positively affects the recipient's willingness to purchase;

H6c: The objectivity of the sender of the tourist destination information positively affects the recipient's willingness to purchase;

H6d: The strength of the relationship between the sender and the recipient of the tourist destination information positively affects the recipient's willingness to purchase.

\section{Information Recipient Level}

Chen (2008) believes that the altruistic motivation of the information recipient is very important in the network environment. Dichter (1966) suggested that in the context of word-of-mouth, strong appetite for products would ease tension; Amdt (1967) pointed out that there is a link between involvement and word-of-mouth; Bloemer et al. (1999) also proved that there is a certain relationship between them. Celsi and Olson (1988) argues that in ELM, involvement is related to the motivation to process information, and high involvement drives consumers to be more motivated to search for word of mouth, understand and process information, and low-involved consumers. There is no motivation to process information. Zhang (2013) believes that the product involvement of online word-of-mouth recipients has a positive effect on the effect of online wordof-mouth communication, and can positively influence the re-distribution willingness and willingness of purchase of information recipients; Zhang (2013) also recognized that the level of product involvement of online word-of-mouth information recipients will positively influence consumers' purchasing decisions. According to the judgment of the above scholars and the author's definition, the assumptions at the information receiver level are as follows:

H7a: The altruistic motivation of the recipient of the tourist destination information is positively affecting its willingness to re-transmit;

$\mathrm{H} 7 \mathrm{~b}$ : The product involvement of the recipient of the tourist destination information is positively affecting its willingness to re-transmit;

H8a: Product involvement of recipients of travel destinations positively affects their willingness to purchase;

H8b: The payment ability of the recipient of the tourist destination information positively affects the willingness to purchase;

\section{RESEARCH DESIGN}

\section{A. Questionnaire Design}

For the level of propagation effects, mainly combined with Sun et al.(2006), Chen and Zhang (2008), Bansal and Voyer (2000); the information level of measurement scale mainly utilized Zhang (2013); measure channel source credibility level of the main reference Belle CHAN (2008);communicators source credibility constructs measured main reference Belle CHAN (2008), Chengxiu Fang (2011)of the measure; recipients The construction of the level mainly refers to the research results of Chai (2011) and Zhang (2013).

\section{B. Sample Collection and Data}

The research object of this research is mainly for those who may or actually publish the word-of-mouth information of the destination on the network platform, and the research object must use the Internet, because the research object is completely selected through the Internet platform. For the sampling conditions, this paper Weibo, WeChat, forum 
placement and other methods were used to conduct random and convenient sampling, and the questionnaire was distributed by means of the questionnaire online questionnaire. Based on this, the survey mainly adopts two methods: first, sending the questionnaire to friends, classmates, and enterprise employees through e-mail for investigation; second, setting up a questionnaire on the professional survey website questionnaire (SOJUMP), Weibo, WeChat, and community forums were conducted in a survey. Due to the distribution through the Internet platform, it is impossible to count the number of questionnaires sent, and finally 247 questionnaires were collected, and the questionnaires with contradictory and data loop detection were eliminated. A total of 206 valid questionnaires were collected, and the effective questionnaire rate was $83.4 \%$, which basically met the definition before the survey.

\section{Reliability and Validity Analysis}

The overall reliability of the questionnaire is 0.904 , and satisfying the Cronbach CITC deleted items greater than less than $0.5 \alpha$ coefficient, meanwhile, all items Cronbach $\alpha$ coefficient is greater than 0.7 , indicating that the reliability is good, and all the items in the questionnaire can be retained

In terms of validity, the factor analysis method in SPSS software is mainly used. Among them, KMO is 0.785 , and the Bartley ball type test with a significance level of 0.05 is passed, and the variance contribution rate analysis table can be known and a total of 33 questions can be extracted from eight main components; the eight main factors explain the variance accounted for nearly $67.507 \%$, which the author believes that this extracted eight common factors in the full extraction of information and interpretation of the original variables The aspect is ideal. Observing the rotated factor load matrix, the 33 items are loaded on only one principal component, and the load coefficients on other principal components are less than 0.4. It can be known that each item in the questionnaire is valid, and the overall questionnaire structure has good validity.

\section{MODEL AND HYPOTHESIS TESTING}

The author fits Index Mplus 7.4 software verification model, CMIN / DF, S RMR, CFI, GFI, RMSEA like fitting indicator value $2.83,0.05,0.919,0.909$, and 0.06 , each quasi found the fitness index is within the recommended range and can accept the theoretical model defined by the study.

Three hypotheses are rejected through empirical research ("Table I"), which are: (1), the information on the potency of the tourist destination will positively affect the consumer's willingness to purchase is rejected, the actual situation is negative, and the possible reason is that the higher the evaluation of a certain destination on the Internet, the more disgusting consumers are. For each unit of evaluation, the consumer's willingness to shop at a destination is reduced by 0.565 ; (2) The strength of the relationship between the sender and the recipient of the online word-of-mouth information is counterproductive to the recipient's willingness to re-transmit, contrary to the original hypothesis, which means that the closer the relationship is, the more unfavorable the realization of the willingness to re-transmit; (3) the third hypothesis of rejection is that the altruistic motives of the recipients of the destinations are positively affecting their willingness to re-transmit. In the survey, this situation is the opposite. The higher the altruistic motivation of the recipient of the information, the weaker the willingness to re-transmit will be.

TABLE I. RESUlT OF STRUCTURAL EQUATION MODEL

\begin{tabular}{|c|c|c|c|}
\hline Hypothesis & Hypothetical description & Estimate & Test \\
\hline H1a & $\begin{array}{l}\text { The information titer of the word-of-mouth information of the tourist destination } \\
\text { will positively affect the willingness to propagation the word-of-mouth }\end{array}$ & $0.143 * * *$ & Accept \\
\hline$H 1 b$ & $\begin{array}{l}\text { The information intensity of word-of-mouth information in tourism destinations will } \\
\text { positively affect the willingness to propagation online word-of-mouth }\end{array}$ & $0.563 * * *$ & Accept \\
\hline HIc & $\begin{array}{l}\text { The information quality of the word-of-mouth information of tourist destinations } \\
\text { will positively affect the willingness to propagation the word-of-mouth }\end{array}$ & $0.598 * *$ & Accept \\
\hline $\mathrm{H} 2 \mathrm{a}$ & $\begin{array}{l}\text { The information titer of the word-of-mouth information of the tourist destination } \\
\text { will positively affect the willingness of the recipient of the information to purchase }\end{array}$ & $-0.565 * * *$ & Reject \\
\hline$H 2 b$ & $\begin{array}{l}\text { The strength of the word-of-mouth information of the tourist destination will } \\
\text { positively affect the willingness of the recipient to purchase the information. }\end{array}$ & $0.905^{* *}$ & Accept \\
\hline $\mathrm{H} 2 \mathrm{c}$ & $\begin{array}{l}\text { The information quality of the word-of-mouth information of the tourist destination } \\
\text { will positively affect the willingness of the information receiver to purchase. }\end{array}$ & $0.393 * *$ & Accept \\
\hline $\boldsymbol{H 3}$ & $\begin{array}{l}\text { The credibility of the target information channel (website) is positively affecting the } \\
\text { re-distribution willingness of the recipient of the information }\end{array}$ & $0.888^{*}$ & Accept \\
\hline H4 & $\begin{array}{l}\text { The credibility of the target information channel (website) is positively affecting the } \\
\text { willingness of the recipient of the information }\end{array}$ & $0.782 * * *$ & Accept \\
\hline H5a & $\begin{array}{l}\text { The professionalism of the sender of the tourist destination information positively } \\
\text { affects the recipient's willingness to re-transmit }\end{array}$ & $0.784 * * *$ & Accept \\
\hline$H 5 b$ & $\begin{array}{l}\text { The reliability of the sender of the tourist destination information positively affects } \\
\text { the recipient's willingness to re-transmit }\end{array}$ & $0.818^{* *}$ & Accept \\
\hline $\mathrm{H} 5 \mathrm{c}$ & $\begin{array}{l}\text { The objectivity of the sender of the tourist destination information positively affects } \\
\text { the recipient's willingness to re-transmit }\end{array}$ & $0.459 * *$ & Accept \\
\hline H5d & $\begin{array}{l}\text { The relationship between the sender and recipient of the tourist destination } \\
\text { information positively affects the recipient's willingness to re-transmit }\end{array}$ & $-0.627 * *$ & Reject \\
\hline H6a & $\begin{array}{l}\text { The professionalism of the sender of the tourist destination information positively } \\
\text { affects the recipient's willingness to purchase }\end{array}$ & $0.882 * * *$ & Accept \\
\hline
\end{tabular}




\begin{tabular}{|c|c|c|c|}
\hline Hypothesis & Hypothetical description & Estimate & Test \\
\hline$H 6 b$ & $\begin{array}{l}\text { The reliability of the sender of the tourist destination information positively affects } \\
\text { the recipient's willingness to purchase }\end{array}$ & $0.78 * *$ & Accept \\
\hline H6c & $\begin{array}{l}\text { The objectivity of the sender of the tourist destination information positively affects } \\
\text { the recipient's willingness to purchase }\end{array}$ & $0.479 * *$ & Accept \\
\hline H6d & $\begin{array}{l}\text { The relationship between the sender and the recipient of the tourist destination } \\
\text { information positively affects the recipient's willingness to purchase }\end{array}$ & $0.605^{*}$ & Accept \\
\hline H7a & $\begin{array}{l}\text { The altruistic motives of recipients of tourist destination information are positively } \\
\text { affecting their willingness to re-transmit }\end{array}$ & $-0.44 * *$ & Reject \\
\hline$H 7 b$ & $\begin{array}{l}\text { The product involvement of the recipient of the tourist destination information } \\
\text { positively affects its willingness to re-transmit }\end{array}$ & $0.579 * * *$ & Accept \\
\hline $\mathrm{H} 8 \mathrm{a}$ & $\begin{array}{l}\text { The product involvement of the recipient of the tourist destination information } \\
\text { positively affects the willingness to purchase }\end{array}$ & $0.806^{* *}$ & Accept \\
\hline $\mathrm{H} 8 \mathrm{~b}$ & $\begin{array}{l}\text { The ability of recipients of travel destination information to positively affect their } \\
\text { willingness to purchase }\end{array}$ & $0.514^{*}$ & Accept \\
\hline
\end{tabular}

\section{CONCLUSION}

The re-distribution willingness of word-of-mouth recipients determines the speed and propagation of word-ofmouth in the network, and the word-of-mouth recipients who are more willing to propagation will quickly propagation to as many other recipients as possible; weak word-of-mouth recipients will stop propagating or only propagating to a small number of other recipients. The second effect of online word-of-mouth communication should be reflected in the purchase decision. Online word-of-mouth is an important decision-making basis for consumers to reduce search costs and perceived risks in the current environment of asymmetric information.

The professionalism, homogeneity of the word-of-mouth sender, the strength of the relationship between the sender and the recipient of the word-of-mouth, and the credibility of the website significantly positively affect the influence of online word-of-mouth on consumer behavior, and this influence is trusted through online word-of-mouth. The intermediary role is achieved. The professionalism of wordof-mouth recipients not only significantly affects the online word-of-mouth effect, but also regulates the relationship between word-of-mouth sender characteristics, website credibility and network word-of-mouth credibility. When word-of-mouth recipients are highly professional, they tend to use the professionalism of word-of-mouth senders as a clue to building trust; and when word-of-mouth recipients are less professional, they tend to use website credibility as a clue to building trust.

\section{REFERENCES}

[1] Kozinets R V. E-tribalized marketing? The strategic implications of virtual communities of consumption [J]. European Management Journal, 1999, 17(3): 252-264

[2] Godes D, Mayzlin D. Using online conversations to study word-ofmouth communication [J]. Marketing science, 2004, 23(4): 545-560.

[3] Westbrook, R. Product Consumption-based Affective Response and PostPurchaseProcess [J]. Journal of Marketing Research.1987, 24:258-270

[4] Chevalier J A, Mayzlin D. The effect of word of mouth on sales: Online book reviews $[\mathrm{J}]$. Journal of marketing research, 2006, 43(3): 345-354.
[5] Bansal P, Roth K. Why companies go green: A model of ecological responsiveness [J]. Academy of management journal, 2000, 43(4): 717-736.

[6] Bansal, H.S., Voyer, P.A. Word-of-mouth processes within a services purchase decision context. Journal of Service Research, 2000, 3 (2):166-177.

[7] Baggozzi, R. P., Yi, Y. On the evaluation of structural equation models. Journal of the Academy of Marketing Science, 1988, 16(1): 74-94.

[8] Katz,E.; Lazarsfeld, P.F.. 1964. Personal Influence: The Part Played by People in the Flow of Mass Communication [M]. New York: The Free Press, 72- 75.

[9] Dellarocas, Chrysanthos. 2003. The Digitization of Word-of-Mouth Promise and Challenges of Online Feedback Mechanisms. ManagementScience. 49 (10): 1407-1424.

[10] Duhan, Johnson, Wileox, Harrel. Influences on consumer use of word of mouth Recommendation Sources [J]. Journal of the Aeademy of Marketing science. 1997, 25(4): 283-295. 